\title{
Politisk opbrud i den folkelige idræt i mellemkrigstiden ${ }^{1}$
}

\author{
af Torben Jacobsen
}

\section{Legemskultur - sport-idræt. Indledende definitioner.}

Udgangspunktet for mit arbejde er, at det er frugtbart at genindføre den gamle skelnen mellem begreberne sport og idræt.

Ordet ,idræt“" er et gammelt dansk ord, udgået fra oldnordisk, der oprindeligt betegnede enhver oplært eller højt udviklet færdighed af såvel åndelig som legemlig art. Ordet ,,sport" er afledt af det franske ,,desport“ og blev omkring 1500 i England anvendt om landadelens fritidsfornøjelser: Ridning, rævejagt, falkejagt og kapløb.

I dag er man hovedsageligt gået over til at anvende begreberne idræt og sport om de samme fænomener inden for den brede betegnelse legemsøvelser, eller legemskultur. Dog med den begrænsning, at enhver form for idræt kan betegnes som sport, mens det omvendte ikke er tilfældet (f.eks. er der nok kun få, der vil gå så vidt som til at betegne motorsport som idræt).

Her vil jeg knytte an til den nyeste danske sportsforskning, der med kraftcentrum omkring Gerlev Idrætshøjskole (som bl.a. siden 1980 har udgivet tidsskriftet ,,Centring - Krop og sport“) er nået frem til en erkendelse af, at alle fra historien kendte former for kulturer og kulturepoker har haft en dominerende form for legemskultur (leg, spil, fysisk træning og hærdning etc.), ofte med en tydelig adskillelse mellem overklassens og underklassens legemskultur. Denne var frem til ca. 1800, mange særegne træk usagte, navnlig kendetegnet ved få, eller ingen regler og megen brutalitet - en opfattelse, der hviler på mange internationale forskeres beskæftigelse med de forskellige kulturepoker ${ }^{2}$

Sporten derimod, opstod i England omkring 1800 med et mere og mere forfinet net af standardiserede regler og lavere (kontrolleret) grad af voldsanvendelse, samt specialisering (udparcellering) af den legemlige aktivitet. Der har $\mathrm{i}$ tidsskriftet Centring fundet en diskussion sted mellem navnlig $\mathrm{O}$.

1 Artiklen bygger på mit speciale ved Historisk Institut, Århus Universitet fra 1982. Specialet er i 1983 optrykt af DDG\&U og kan erhverves ved henvendelse til organisationen. Torben Jakobsen: Legemskultur i mellemkrigstiden. 1982.

2 Jvf. f.eks. G. Patriksson: Idrottens historie. 1973. K. Rittner: Sport und Arbeitsteilung. 1976. J. Walvin: The Peoples Game. 1975. 
Korsgaard og J. Øllgaard, om fremvæksten af den moderne sport hang sammen med kapitalismens eller industrikulturens gennemslag ${ }^{3}$. Jeg mener med Øllgaard, at sporten i sit væsen først og fremmest hænger sammen med kapitalismen, idet begge fænomener bygger på konkurrence, præstation og formel (institutionaliseret) lighed. Samtidigt er det klart, at det i første række er konkurrencen, der under kapitalistiske forhold behersker samfundet og de menneskelige omgangsformer, herunder sporten.

På det mere konkrete niveau er der derimod en klar sammenhæng mellem industrialisering og urbanisering under kapitalismen og sportens fremvækst, hvor Korsgaards nøgleord om bl.a. standardisering, specialisering og centralisering af samfundet og legemskulturen kan anvendes. Man kan også med $\mathrm{N}$. Kayser Nielsens ord sige, at massesporten dukker op, hvor der er et sammenfald mellem kapitalisering, industrialisering og urbanisering. ${ }^{4}$

Dette sammenfald fandtes $i$ de fleste lande $i$ forrige århundrede, hvorfor sporten hurtigt udviklede sig til at blive den dominerende form for legemskultur.

Der var dog enkelte lande, der afveg fra dette mønster, f.eks: Danmark, hvor sporten først blev organiseret på landsplan med oprettelsen af Dansk Idræts Forbund i 1896, og nogen egentlig dominans udvikledes ikke før langt op i det 20. århundrede.

Den dominerende form for legemskultur var derimod skydning og gymnastik inden for De Danske Skytteforeninger, der var opstået i 1861. (Se i øvrigt fig. 1).

Fig. 1. Hovedorganisationernes stiftelsesår

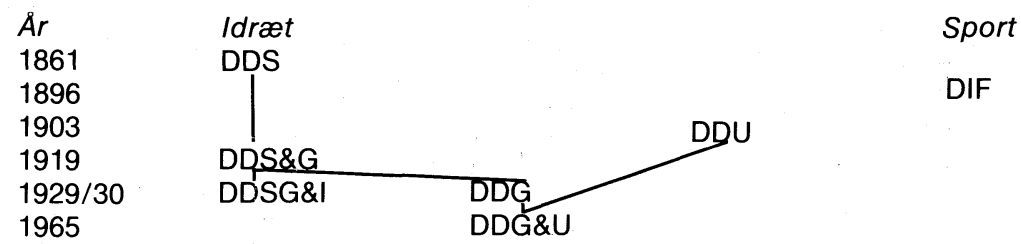

Forkortelser:

DDS: De Danske Skytteforeninger

DDS\&G: De Danske Skytte- og Gymnastikforeninger

DDSG\&I: De Danske Skytte-Gymnastik-og Idrætsforeninger

DDG\&U: De Danske Gymnastik-og Ungdomsforeninger

DDU: De Danske Ungdomsforeninger

DIF: Dansk Idræts Forbund

DDG: De Danske Gymnastikforeninger

3 Jvf. specielt Centring nr. 3, 1980 og nr. 1-2, 1981.

4 N. Kayser Nielsen: Sport, kultur og utopi. Bidrag nr. 13-14, 1981, side 18. 
Her mener jeg det for at skabe begrebslig afklaring vil være gavnligt at indføre anvendelsen af det gamle nordiske ord idræt. Ved idræt vil jeg teoretisk forstå de organiserede legemlige aktiviteter, der udøves med en alsidig fysisk udvikling for øje, og som opstiller ideelle mål, udover disse rent legemlige, af psyko-social eller politisk-ideologisk art.

Ved sport vil jeg derimod forstå de organiserede legemlige aktiviteter, der udøves i specialiseret retning og (pånær visse sundhedsideer) ikke opstiller andre mål end en videre udvikling og forbedring af disse aktiviteter, især med henblik på bedre konkurrenceresultater.

Sporten - fra 1896 organiseret i DIF - hentede fra starten hovedsageligt sine udøvere i de største byer, en tendens, der har holdt sig frem til i dag, med medlemsmæssige koncentrationer i de urbane områder.

At sporten først og fremmest var et byfænomen, hang dybest set sammen med, at det navnlig var her de kapitaliserede livsformer slog igennem. Kendetegn herfor var f.eks. den direkte indbyrdes konkurrence mellem de handlende, den industrielle rytmiks krav om opdeling af dagen i afmålte tidsenheder, og i det hele taget fokuseringen på den dygtiges egenskaber.

Da Danmark var et landbrugsland med en begrænset urbanisering og industrialisering, var der fra starten af dette århundrede sat en grænse for sportens udbredelse. Først i løbet af 1930'rne fik byerhvervene større nationaløkonomisk betydning end landbruget. Urbaniseringsprocessen forløb forholdsvis langsomt: Bybefolkningen udgjorde i $1921.54,3 \%$, i 1930 $58,4 \%$, og i $194063,5 \%$ af den samlede befolkning. ${ }^{5}$

Denne udvikling levnede plads til konsolidering af den særegne folkelige idræt.

Denne legemskultur søgte at give de aktive en alsidig legemlig udvikling, og at give så mange som muligt (om fornødent til dels på bekostning af de dygtiges udvikling) bestemte fysiske og psykiske påvirkninger, som oftest sammenfattet i slagordene: En sund sjæl i et sundt legeme!

At den folkelige idræt foregik i landdistrikterne var i logisk overensstemmelse med, at den frie konkurrence her blev holdt i skak af andelsbevæge/sens store udbredelse. Den individuelle konkurrence (præstation) måtte i såvel produktion som i idrætten ikke undergrave fællesskabets interesser. Desuden indrettede man sig efter arbejdets sæsonsvingninger, så den største aktivitet, hold-gymnastikken, blev henlagt til den forholdsvis arbejdslette vintertid.

De Danske Skytteforeninger havde udelukkende skydning på programmet. Efterhånden kom gymnastikken til, hvilket bl.a. nødvendiggjorde navneæn-

5 O. Degn: Urbanisering og industrialisering. Kbh. 1978. side 105. Ved en by forståes her en afgrænset bebyggelse på over 250 indbyggere. 
dringen i 1919 til ,De Danske Skytte- og Gymnastikforeninger“ (DDS\&G).

I 1929/30 blev den folkelige idræt splittet i 2 organisationer, gennem et politisk oprør, som jeg vil redegøre nærmere for nedenfor. Afslutningsvis skal det blot nævnes, at den nye udbryderorganisation fra 1929, ,De Danske Gymnastikforeninger" (DDG), i 1965 blev sluttet sammen med det landsdækkende ungdomsforbund, DDU, der fortrinsvis havde folkedans og foredrag på programmet, så vi i dag har 2 idrætsorganisationer: DDSG\&l og DDG\&U, samt en sportsorganisation: DIF.

\section{Det politiske opbrud i $1929 / 30$}

Den folkelige idræt havde fra starten i 1861 klare politiske mål, af national og militær art: Det drejede sig om at opdrage folket til fædrelandskærlighed og styrke viljen til med våben $\mathrm{i}$ hånd at værne fædrelandet. Efter krigsnederlaget i 1864, hvor det sydlige Jylland blev afstået til Tyskland, blev det erklærede mål desuden at vinde dette landområde tilbage.

Op gennem historien stod der megen blæst $i$ organisationen om disse formålserklæringer, hvorfor de da også blev ændret og modificeret flere gange.

Overfladisk betragtet blev diskussionerne ført mellem to medlemsgrupper; skytterne og gymnasterne.

Gymnasterne, der fra århundredskiftet var i markant overtal, kæmpede for at blive accepterede på linie med skytterne, der som organisationens grundlæggere, opfattede gymnasterne som andenrangs medlemmer.

Inden for den traditionelle danske idrætshistorie, specielt som den er blevet fremstillet af organisationerne selv, er det som oftest blevet hævdet, at disse medlemsmæssige stridigheder var den egentlige årsag til idrættens organisatoriske omdannelser, herunder til splittelsen i 1929/30. ${ }^{6}$

Af en undersøgelse jeg har foretaget i 1982 fremgår imidlertid, at begivenhederne i 1929/30 havde klare politiske overtoner, hvor den nye organisation (DDG) orienterede sig mod Det Radikale Venstre. Den gamle organisation (DDSG\&l) sympatiserede derimod med de højreorienterede partier Venstre og Det Konservative Folkeparti. Stiftelsen af DDG markerede et oprør mod disse højreorienterede sympatier i den folkelige idræt - og fremfor alt mod militarismen i organisationen.

Den landspolitiske baggrund var følgende: Venstre, der havde regeret

6 Jvf. f.eks.: A. Alstrup: 25 års idræt i DDSG\&l. Vol.1.1957 s. 34-35. P. Christiansen: DDSG\&I 1861-1971. Kbh. 1971 s. 132-134. K. Gundersen et.al: DDG 1929-1954. Vejle 1954 s. 25-26. DDG\&U: Det hele menneske. Vejle 1979. s. 22-23+27. 
siden 1926 med støtte fra de Konservative, var i 1928 blevet uenig med sit støtteparti om omfanget af bevillingerne til det danske militærvæsen, bl.a. på baggrund af Socialdemokratiets og de Radikales stærke nedrustningspropaganda. Dette førte til regeringens afgang i foråret 1929. Valgkampen formede sig som et voldsomt angreb fra Radikale Venstres og Socialdemokratiets side (disse partier havde indgået borgfred) på de borgerliges forsvarspolitik, hvorved hovedspørgsmålet $\mathrm{i}$ vidt omfang blev ja eller nej til nedrustning. Resultatet af valget blev en klar sejr til nedrustningslinien.

En række indicier antydede, at stiftelsen af DDG i efteråret 1929 knyttede an til denne debat, og reelt var et politisk opror mod den borgerligt dominerede ledelse i DDS\&G.

For det første orienterede de involverede personer sig klart $\mathrm{i}$ forskellig retning i det politiske spektrum. Formanden for DDS\&G hed H. Parkov og var medlem af Folketinget for de Konservative (og oberst $\mathrm{i}$ hæren). To af de mest ihærdige modstandere af DDG blandt gymnastiklederne hed Arnth Jensen og K. Kristensen, og de var begge medlem af Folketinget for Venstre. (Arnth Jensen blev i øvrigt senere, fra 1934 til 1963, formand for DDSG\&I). Desuden spillede Niels Bukh en afgørende rolle $i$ begivenhederne. Han var i foråret 1929 med i et udvalg, der blev nedsat med det formål at indkalde til stiftende generalforsamling i DDG, og i øvrigt varetage indmeldelser heri. Men Bukh trak sig hurtigt ud af dette arbejde, fordi, som han udtalte, ,der var gået politik i sagen".7 Når man betænker $\mathrm{N}$. Bukhs stærkt højreorienterede politiske sindelag, der senere udviklede sig til klare nazistiske sympatier, var det ikke svært at gætte sig til, hvilken del af det politiske spektrum han hentydede til i sin kritik af initiativtagerne til DDG. Herefter gik han i øvrigt aktivt ind $i$ arbejdet for at bevare den gamle forening under nye former, det der i 1930 blev til DDSG\&I.

Foregangsmændene for DDG orienterede sig derimod i retning af Det Radikale Venstre, ligesom aviser og tidsskrifter tilknyttet dette parti forsvarede den organisatoriske nyskabelse. Særlig markant var her tidsskriftet „Nye Veje", der førte en veritabel agitationskampagne for stiftelsen af DDG. ${ }^{8}$

Et andet indicium var den årlige statsstøtte, der blev bevilget til idrætten over finansloven. DDS\&G fik ikke blot et samlet beløb stillet til rådighed, pengene blev på forhånd øremærket til enten gymnasterne (hvor tilhængere af Det Radikale Venstre var i overtal), eller til skytterne (hvor der var overvægt af tilhængere af partierne Venstre og Det Konservative Folkeparti).

7 Ungdom og Idræt. Vejle 1929 side 305-307.

8 Nye Veje. 1929. Kbh. F.eks. s. 72-73.

9 Idrætshistorisk Årbog 
Fig. 2. Statsstøttens fordeling mellem skytter og gymnaster inden for De Danske Skytte- og Gymnastikforeninger-ydet over finanslovene i perioden 1919-1930.

\begin{tabular}{lccccl}
\hline & \multicolumn{2}{c}{ skytterne } & \multicolumn{2}{c}{ gymnasterne } \\
finansår & beløb & antal & beløb & antal & regering \\
\hline $1919-20$ & 68000 & 19950 & 24000 & 22600 & Neergaard (1920-) \\
$1920-21$ & 68000 & 21690 & 50000 & 24890 & --- \\
$1921-22$ & 81000 & 21780 & 50000 & 29090 & --- \\
$1922-23$ & 70000 & 18090 & 40000 & 38500 & --- \\
$1923-24$ & 56000 & 15840 & 36000 & 41660 & --- \\
$1924-25$ & 56000 & 15000 & 36000 & 41320 & --- \\
$1925-26$ & 26000 & 13410 & 36000 & 40980 & Stauning (april 1924-) \\
$1926-27$ & 25500 & 15820 & $64400^{1}$ & 46060 & --- \\
$1927-28$ & 40300 & 18110 & 49900 & 52720 & Madsen-Mygdal (dec. 1926-) \\
$1928-29$ & 40300 & 17200 & 49900 & 54720 & --- \\
$1929-30$ & 17000 & 14550 & 43000 & 62502 & Stauning-Munch (april 1929-) \\
\hline
\end{tabular}

Kilde: DDS\&G's årsberetninger 1919-30 og Rigsdagstidende 1919-30.

1) Fra og med 1926-27 blev den særlige støtte til uddannelse af delingsførere også fordelt mellem skytter og gymnaster i regnskaberne.

Der er overalt ved ,beløb" tale om hele kr.!

På vedtagelserne i Folketinget i 20 'rne kunne man tydeligt aflæse de skiftende regeringers sympati for den ene eller anden fløj $i$ den folkelige idrætsbevægelse. Da den første socialdemokratiske mindretalsregering havde magten fra 1924 til 1926, (Stauning) støttet af Det Radikale Venstre, blev gymnasterne favoriseret, det samme gentog sig fra 1929, hvor De Radikale indgik i regeringskoalition med Socialdemokratiet (Stauning-Munch). Før 1924 - og mellem 1926 og 1929, hvor Venstre regerede støttet af de Konservative, var det derimod skytterne, der blev favoriseret. (Neergaard og Madsen-Mygdal). (Jvf. i øvrigt Fig. 2).

Til støtte for disse indicier har jeg gennemført en sammenligning mellem fordelingen af Det Radikale Venstres vælgerhøjborge ved valget i 1929, og fordelingen af DDG's aktive, voksne medlemmer ved stiftelsen i vinteren 1929/30.

Medlemssituationen ved splittelsen fremgår af følgende tabel: (Tallene yderst til højre i tabellen skal sammenholdes med de små tal på Danmarkskortet i fig. 3). 
De aktive gymnasters geografiske spredning i 1930

\begin{tabular}{lrrr}
\hline Amtsforening & $D D G$ & $D D S G \& I$ & Fig. 3 \\
\hline København & 2806 & 2657 & 12 \\
Roskilde & 1295 & 563 & 13 \\
Frederiksborg & 0 & 1119 & 14 \\
Holbæk østre & 1576 & 554 & 15 \\
Holbæk vestre & 0 & 2591 & 16 \\
Sorø & 0 & 2836 & 17 \\
Præstø & 2860 & 0 & 18 \\
Møen & 0 & 220 & 19 \\
Maribo & 1405 & 324 & 20 \\
Bornholm & 0 & 447 & 21 \\
Odense & 3506 & 0 & 22 \\
Svendborg & 3511 & 161 & 23 \\
Hjørring & 1362 & 0 & 24 \\
Himmerland/Aalborg & 875 & 867 & 25 \\
Salling & 932 & 0 & 26 \\
Thisted & 756 & 0 & 27 \\
Morsø & 547 & 0 & 28 \\
Ringkøbing & 2086 & 479 & 29 \\
Hammerum Herred & 0 & 555 & 30 \\
Viborg & 1310 & 0 & 31 \\
Randers & 837 & 685 & 32 \\
Hobroegnen & 291 & 0 & 33 \\
Århus & 1521 & 15 & 34 \\
Skanderborg & 727 & 67 & 35 \\
Horsensegnen & 1113 & 0 & 36 \\
Vejle & 458 & 1761 & 37 \\
Ribe & 2855 & 368 & 38 \\
Sønderjylland & 277 & 3153 & 39 \\
\hline I alt: & 32906 & 19422 & \\
\hline & & & \\
\hline
\end{tabular}

Landsstyrelsen for DDG: Årsberetning 1931. p. 22. Overbestyrelsen for DDSG\&l: Årsberetning 1931. p. 37. 
Fig. 3. Amtsforeningsgrænser i 1930 og den amtskommunale inddeling fra 1970.

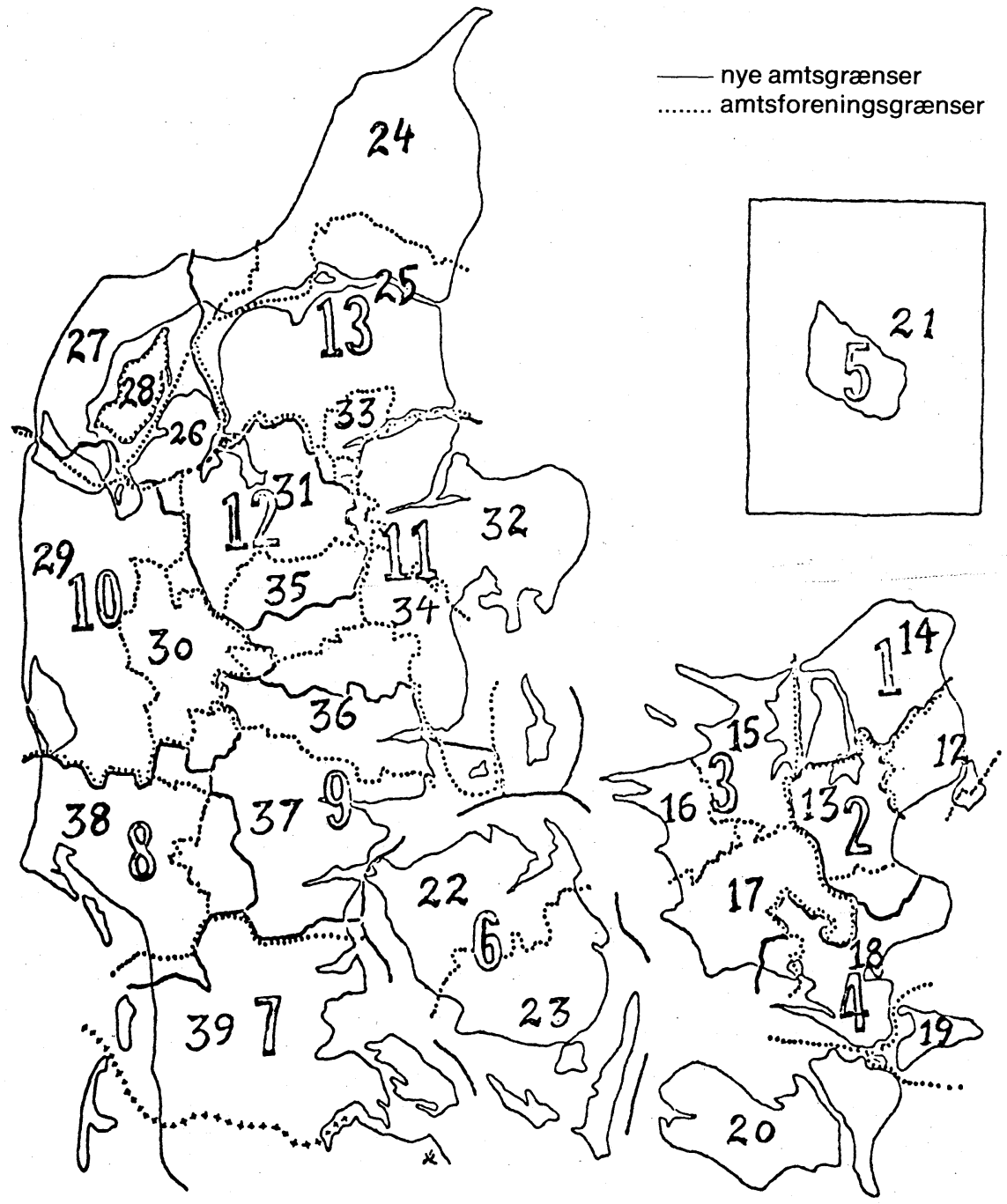

De små ta/ henviser til amtsforeningerne i DDG og/eller DDSG\&l nævnt i tabel 7.

De store tal henviser til den amtskommunale inddeling fra 1.4.1970: 1. Frederiksborg, 2. Roskilde, 3. Vestsjælland, 4. Storstrømmen, 5. Bornholm, 6. Fyn, 7. Sønderjylland, 8. Ribe, 9. Vejle, 10. Ringkøbing, 11. Aarhus, 12. Viborg, desuden Kbh. og Frederiksberg kommuner samt Kbh's amtskommune.

Kilde: Betænkning afgivet bilag 8, Glargaard side 194-195, DDG: års 1931 og DDSG\&l: års 1931. 
Tabellen gælder kun gymnasterne, skyttegruppen, der omfattede ca. 14000 personer blev ikke splittet, men fortsatte i DDSG\&I. Af tabellen fremgår, at DDG stod stærkest på øerne, både absolut og i forhold til DDSG\&I. Dette var særligt markant tilfældet på Fyn (nr. 22 + 23). På Sjælland drejede det sig om områderne omkring Holbæk (nr. 15), Præstø (nr. 18), og Maribo (nr. 20). I Jylland var de mest markante områder omkring Hjørring (nr. 24), Ringkøbing (nr. 29), Viborg (nr. $31+26)$, Horsens (nr. $35+36$ ) og Ribe (nr. 38). Som det tidligere er bemærket var det uden for de deciderede byområder, at idrætten hentede de fleste af sine medlemmer. Situationen i København (nr. 12) og Århus (nr. 34) dannede dog en undtagelse fra denne regel, idet DDG havde en hel del (overvejende kvindelige) medlemmer begge steder.

Hele dette billede vil jeg i det følgende sammenligne med resultatet af valget den 24.4.1929, idet det var dette valg, der indgik i hændelsesforløbet omkring DDG's dannelse, og i øvrigt var tættest herpå. (Det foregående valg var i 1926, det følgende kom i 1932.) Ved dette valg gik Det Radikale Venstre lidt frem i stemmetal til 10,7\% af de afgivne stemmer, men fik uforandret 16 mandater.

En første undersøgelse af valgresultatet viser, at de radikale stod stærkest på øerne (med 15,8\% af stemmerne), ligesom DDG gjorde. Går man nærmere ind herpå, vil en højborg for partiet være et afstemningsområde, hvor det har opnået mere end $15,8 \%$ af stemmerne, hvilket var tilfældet i områderne; Holbæk, Maribo, Præstø og på Fyn. Sammenhængen med DDG-dominerede områder var her meget tydelig.

I Jylland fik Det Radikale Venstre 8,6\% af de afgivne stemmer, med højere andele i Hjørring, Viborg, Skanderborg og Ribe amtskredse. Dette svarer ved en nøjere analyse til områderne $24,31+26$ og 38 i tabellen og på kortet i fig. 3 , netop områder hvor der var en klar DDG dominans.

Herudover var der en klar dominans af DDG gymnastikmedlemmer i Århus amt (nr. 34), Thisted-Mors $ø$ (nr. 27+28) og Ringkøbing (nr. 29) amter, som ikke modsvaredes af høje stemmetal til Det Radikale Venstre.

Baggrunden for DDG's mange medlemmer i de to store byområder Århus og København var muligvis, at partiets samarbejdspartnere i valgkampen, Socialdemokratiet, disse to steder havde absolut flertal af de afgivne stemmer, hvorfor de antimilitaristiske strømninger (som DDG bl.a. byggede på) til fulde havde slået igennem.

At DDG dominerede i Vestjylland generelt (altså også i Ringkøbing og Thisted/Morsø) hang sammen med det nære forhold til ,De Danske Ungdomsforeninger" (DDU), der bl.a. gav sig udslag $i$, at den første formand for DDG, P. J. Skriver, tillige var formand for DDU. DDU var en grundtvigsk parallel til - og modstander af - det indremissionske ungdomsforbund KFUM\&K, og stod særlig stærkt i Vestjylland, hvor organisationens talsmænd 
- der ofte stammede fra de samme kredse, eller var de samme personer, som foregangsmændene for DDG - tydeligt markerede både en modstand mod KFUM\&K og en traditionel grundtvigiansk religiøsitet. Det nære samarbejde mellem organisationerne betød, at også DDG havde stor sympati i denne del af Jylland.

Udover denne lille ekskurs angående forholdene i Vestjylland, mener jeg, at hele undersøgelsen har vist, at DDG ligesom Det Radikale Venstre stod stærkt i Midtjylland, i Ribe amt og i flere amter på øerne (særligt på Fyn), hvorfor indtrykket af stiftelsen af DDG som et politisk opror med tilknytning til det radikale parti er blevet styrket.

\section{Det politiske opbruds betydning i dag}

Det mest interessante ved dette opbrud er faktisk, at den netop beskrevne geografiske fordeling af den folkelige idræts gymnaster har holdt sig frem til i dag. DDSG\&l har skytter jævnt fordelt over hele landet, men organisationens gymnastikgruppe har ingen, eller kun få medlemmer, i Hjørring amt, i Vestjylland, ned gennem Midtjylland og på hele Fyn, samt i Holbæk, Præstø og Maribo. Derimod har DDGU i dag netop medlemsmæssige koncentrationer i disse gamle radikale vælgerhøjborge.

Dette skal ses på baggrund af, at DDG (fra 1965 DDG\&U) under den officielle samarbejdsfacade over for de andre idræts-/sportsorganisationer, har fulgt oprøret i 1929 op med jævne mellemrum i årene frem til i dag. Man kan faktisk tale om, at der i DDG\&U er tradition for et vist ,oprørsk element “ $i$ forholdet til den øvrige idrætsverden, hvad nedenstående oversigt i punktform kan vise:

1929: Oprøret mod militarismen/konservatismen.

1938: Vedtagelse af resolution vendt mod nationalisme, specielt som den kom til udtryk i den gamle forening DDS\&G.

1940: (og i øvrigt flere gange i 30'rne) afvisning af Niels Bukhs planer om en enheds ungdomsorganisation (der var inspireret af den tyske naziungdomsorganisation), og i stedet for intrædelse i Dansk Ungdomssamvirke - værnet mod den ",snigende nazisme“ - der senere blev til Dansk Ungdoms Fællesråd.

1948: Modstand mod lov om tipning og nægtelse af at modtage penge herover, dog fik DDG et tilsvarende beløb over finansloven. Modstanden blev opgivet i 1959. 
1955: Under den kolde krig, kontakt med Østeuropæiske ungdomsråd gennem medlemsskabet af Dansk Ungdoms Fællesråd. (Som de andre idrætsorganisationer ikke blev medlem af.)

1960'erne: Vendte DDG\&U sig gentagne gange mod apartheid i Sydafrika.

1978: Optagelse af u-landsarbejde i DDG\&U.

1981: Udmeldelse af Dansk Olympisk Komité. Samme år udvikledes en strid med DIF om medlemsregistrering, der først og fremmest viste vilje og styrke i DDG\&U til at gå sine egne veje inden for den organiserede idrætsbevægelse.

1982: Vendte DDG\&U sig kraftigt mod bebudede nedskæringer i U-landsbistanden.

1983: Tog DDG\&U som den eneste idrætsorganisation afstand fra Faxebryggeriernes kapsel-fiduser, udfra at ledere og aktive havde fornuftigere ting at foretage sig end at samle kapsler og reklamere for et bryggeri.

De to andre store organisationer, DIF og DDSG\&I, har i samme periode stået for de traditionelle synspunkter, og bl.a. søgt at adskille idræt og politik hvorved de har fraskrevet sig muligheden for en velovervejet påvirkning af samfundsforholdene i Danmark. Først efter formandsskiftet i DIF i 1983 er der ved at ske afgørende nyt på denne front - herunder skred i de traditionelle dogmer. Den ovenfor nævnte geografiske fordeling af DDSG\&l's og DDG\&U's medlemmer er naturligvis ikke i dag udtryk for en bestemt partipolitisk stillingtagen, men den er et eksempel på, hvordan de traditionsbestemte vaner påvirker vores dagligdag i større udstrækning, end vi er bevidste om.

Historieforskningen har sin berettigelse bl.a. ved at finde og klarlægge de historiske forudsætninger for de traditioner og regelsæt, der gennemsyrer vores dagligdag.

Selv om mange traditionelt indstillede (idræts)historikere overser, eller direkte forsøger at skjule, ,det politiske“ $i$ samarbejdets og enighedens hellige navn, så er det min holdning, at kun gennem bevidst erkendelse og bearbejdelse af forskellige holdninger og opfattelser kan et frugtbart samarbejde udvikles - den pseudo-enighed, idrættens verden ofte har udvist, narrer efterhånden kun få! Som min undersøgelse har givet et eksempel på, så er vi alle i en vis forstand politisk handlende personer, hvad enten vi er bevidste om det eller ej-også på sportspladsen! 


\section{Fra Pokalturneringen i Idratsparken i Gaar.}

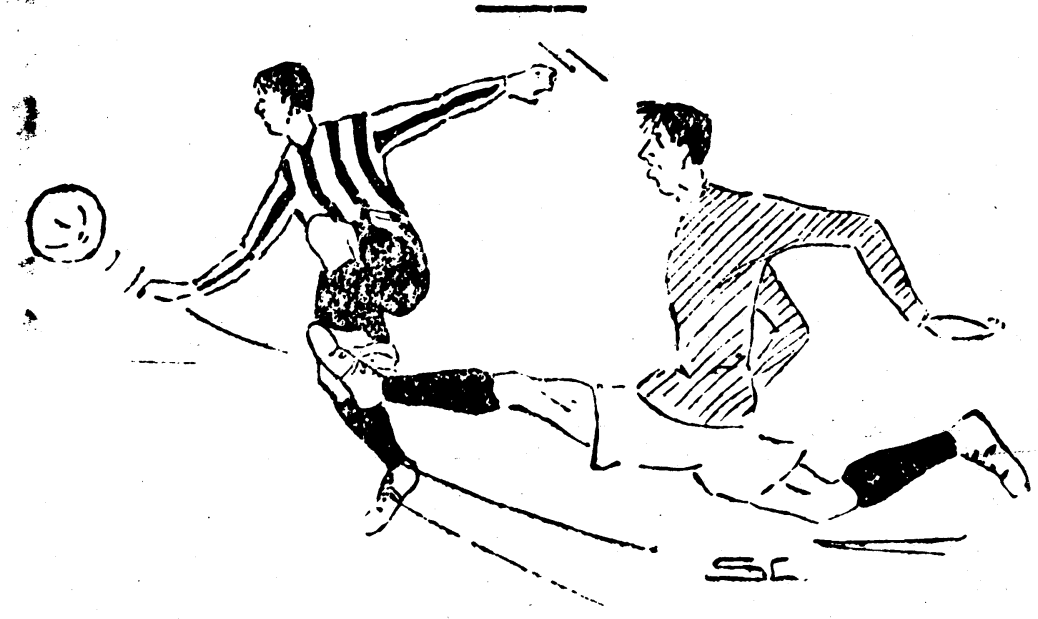

I midste ojeblik.

Ved Pokalkampen paa Idræetsparkens Bane i Gaar mellem A. B. I og B. 1903 I havde Akademikerne atter Leo Frederiksen med I Forsyarsrakken, til Trods for, at han I sidste Sason blev "spendt fra" efter at have "varet for dyr". Om det var af Taknemmelighedsfølelse over for Tilnaadetagelsen eller maaske blot paa Grund af bedre Traning, at A. B.s 3 Alens Bagmand spillede bedre i Gaar, skal vi lade være usagt. Vist er det, at han bestred sin Plads med Hxder, og vor Tegner har oven for gengivet en hidtil uoplevet Situation, i hvilken Leo F. "snød" Carl "Skomager", en Bedrift, der næppe vil gentages ofte, naar de to Berømtheder løber efter samme Bold.

Pokalturneringen 1920. De to „berømtheder", der nævnes $i$ ovennæunte billedtekst skulle blive endnu mere berømte. (Pol. 27.9.1920).

Carl ,Skomager" Hansen fra B1903, der var aktiv i perioden 1915-29 og nåede 7 landskampe gjorde karriere $i$ Glasgow Rangers som centerforward fra 1921-25.

Leo Frederiksen blev senere formand for KBU 1926-31, DBU fra 1940-48 og DIF fra 1947-62. Som aktiv var hans bedste resultat det DM han i 1919 som back vandt med A.B. 